Agricultural Journal 14 (3): 35-39, 2019

ISSN: $1816-9155$

(C) Medwell Journals, 2019

\title{
Length-Weight Relationships of Luciobarbus pectoralis from the Menzelet Dam Lake of Kahramanmaras
}

\author{
${ }^{1} \mathrm{M}$. Özcan and ${ }^{2} \mathrm{U}$. Ispir \\ ${ }^{1}$ Department of Fisheries, Faculty of Agriculture, Kahramanmaras Sutcu Imam University, \\ Kahramanmaras, Turkey \\ ${ }^{2}$ Faculty of Fisheries, Malatya Turgut Ozal University, Battalgazi, Malatya, Turkey \\ mikailozcan@ksu.edu.tr
}

\begin{abstract}
Length-weight relationships are of great value in fisheries research as they are essential to convert length-frequency data into accurate populations estimates and are so often used in stock assessment methods. In this study, the length-weight relationships by sex of the Luciobarbus pectoralis population living in Menzelet Dam Lake (Kahramanmaras) were examined. Fish were caught with gillnets. A total of 150 samples were collected and analyzed. The length-weight relationship was estimated using the linear regression model $\mathrm{W}=\mathrm{aLb}$ and condition factor, $(\mathrm{K})$ determined using the equation $\mathrm{K}=100 \mathrm{~W} / \mathrm{L}^{3}$. Total length of samples ranged between 16.50-20.60 cm (male), 15.50-21.00 cm (female) and weight 30.81-61.64 g (male), 23.87-75.65 g (female) for $L$. pectoralis. The length-weight relationship of fishes were found as $\mathrm{W}=0.067 \mathrm{~L} 1.778$ for all specimens, $\mathrm{W}=0.039 \mathrm{~L} 2.418$ for male and $\mathrm{W}=1.063 \mathrm{~L} 1.228$ for females. Negative allometric growth was recorded for both sexes. The condition factor were varied as 0.731 (all individuals), 0.729 (male) and 0.732 (female) in $L$. pectoralis. The difference of length-weight relationship between $L$. pectoralis was not statistically significant ( $\mathrm{p}$ and gt; 0.05 ). This study, in future has provided baseline information on the LWR and $\mathrm{K}$ of $L$. pectoralis that would be useful for fish biologists and managers to adopt the adequate regulations for sustainable fishery management in the natural water.
\end{abstract}

Key words: Menzelet Dam Lake, fish, Luciobarbus pectoralis, length-frequency data, biologists, LWR

\section{INTRODUCTION}

The Length-Weight Relationship (LWR) studies are considered a prerequisite in fish biology investigations. It is mainly required to know the variations in expected weight from the known length groups which are in turn, the indications of fatness, breeding and feeding state and their suitability to the environment (Saha et al., 2009). Length-length relationships are important for comparative growth studies (Moutopoulos and Stergiou, 2002). Length-length relationships help in the interconversion of total length data with other morphometric characters (Bai and Manimegalai, 2010).

Studies on the length-weight relationship of fishes are important in fishery biology because they allow the estimation of the average weight of fish of a given length group by establishing a mathematical relation between the two (Berg, 1981). The length-weight relationship has been studied by several researchers in different fish species viz., Clarias gariepinus (Ayo-Olalusi, 2014), Oreochromis niloticus (Silva et al., 2015), Astyanax aff. fasciatus
(Furuya et al., 2014), Pseudorasbora parva, Atherina boyeri, Aphanius danfordii, Tinca tinca and Cyprinus carpio (Kirankaya et al., 2014), Capoeta umbla (Serdar and Ozcan, 2016), Acanthobrama marmid, Capoetatrutta, arbusluteus and Chalcalburnusmossulensis (Basusta and Cicek, 2006), Carasobarbus luteus, Chondrostoma regium, Clarias gariepinus, Anguilla anguilla and Cyprinus carpio (Ozcan, 2008).

Condition factor $(\mathrm{K})$ is an important biological parameter which indicates the suitability of a specific water body for the growth of fish and an index of species average size (Bagenal and Tesch, 1978). Condition factor has been studied for different fish species such as Clarias gariepinus (Keyombe et al., 2015), Anabas testudineus (Maurya et al., 2018), Abramis brama (Khristenko and Kotovska, 2017), Capoeta angorae (Emre et al., 2014), Capoeta erhani (Ayyildiz et al., 2014), Silurus glanis (Uysal et al., 2009). The present study aimed to find out the present status of the length-weight relationship and condition factor of

Corresponding Author: Mikail Özcan, Department of Fisheries, Faculty of Agriculture, Kahramanmaras Sutcu Imam University, Kahramanmaras, Turkekey, mikailozcan@ksu.edu.tr 
Luciobarbus-pectoralis. The results play an important role in the management of $L$. pectoralis in the protection program of its natural stocks.

\section{MATERIALS AND METHODS}

Menzelet Dam Lake constructed on the River Ceyhan in the Mediterranean Region of Turkey has a surface area of $42 \mathrm{~km}^{2}$ at $700 \mathrm{~m}$ altitude and it is used for electrical energy production. The maximum depth is $100 \mathrm{~m}$ and the total volume is about $12 \times 10^{9} \mathrm{~m}^{3}$. The fish were collected from December 2012 to October 2014 from the Menzelet Dam Lake (Kahramanmaras-Turkey) (Fig. 1). These samples were collected using gillnets. In the laboratory, Total Length (TL) (in cm), Total Weights (TW) were measured. The sexes were separated after a macroscopic determination of the gonads when the gonads were thin and poorly developed the fish sex was considered as undetermined.

The Length-Weight Relationship (LWR) of a fish was expressed by equation $\mathrm{W}=\mathrm{aTL}^{\mathrm{b}}$ where, $\mathrm{W}$ is the total weight, (TL) is the Total Length, $a$ is the coefficient related to body form and $\mathrm{b}$ is an exponent indicating isometric growth when equal to 3 and allometric growth when different to 3 (the allometry is majorant if $b>3$ and minorant if $b<3$ ). The parameters $a$ and $b$ of the length-weight relationship was estimated by the least-square method using was the dependent variable and TL as the independent variable, $\log (\mathrm{W})=\log (\mathrm{a})+\mathrm{b}$ $\log$ (TL). The b-value for each species was tested by student t-test to verify, if it was significantly different from the predictions for isometric growth $(b=3)$. The Fulton's Condition Factor (cf) was calculated, according to Bagenal and Tesch (1978) with equation:
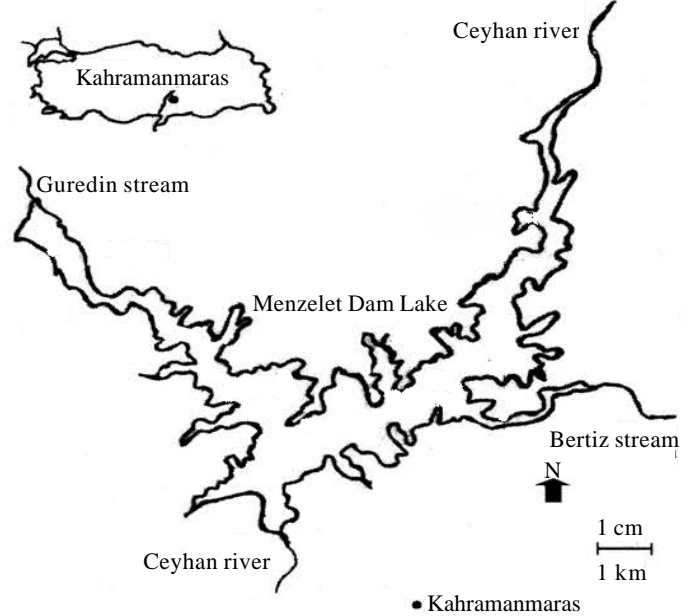

Fig. 1: Menzelet Dam Lake

$$
\mathrm{K}=100 \mathrm{~W} / \mathrm{L}^{3}
$$

Where:

$\mathrm{K}=$ The condition factor $(\mathrm{cf})$

$\mathrm{W}=$ The total Body Weight (BW)

$\mathrm{L}=$ The Carapace Length (CL)

$3=$ Constant

\section{RESULTS AND DISCUSSION}

A total of 150 individuals of $L$. pectoralis were used in this study. LWR is shown in Fig. 2. Total length of samples ranged between $16.50-20.60 \mathrm{~cm}$ (male, $\mathrm{n}=77$ ), $15.50-21.00 \mathrm{~cm}$ (female, $\mathrm{n}=73$ ) and weight $30.81-61.64 \mathrm{~g}$ (male), 23.87-75.65 g (female) for L. pectoralis. The length-weight relationship of fishes were found as $\mathrm{W}=0.067 \mathrm{~L}^{1.778}$ for all specimens, $\mathrm{W}=0.039 \mathrm{~L}^{2.418}$ for male and $\mathrm{W}=1.063 \mathrm{~L}^{1.228}$ for females. Negative allometric growth was recorded for both sexes $(b<3)$. The condition factor were varied as 0.731 (all individuals), 0.729 (male) and 0.732 (female) in L. pectoralis. The difference of length-weight relationship between $L$. pectoralis was not statistically significant ( $>>0.05$ ) (Table 1 ).

Length-weight relationships give information on the condition and growth patterns of fish (Bagenal and Tesch, 1978). In morphometry, length-weight relationships
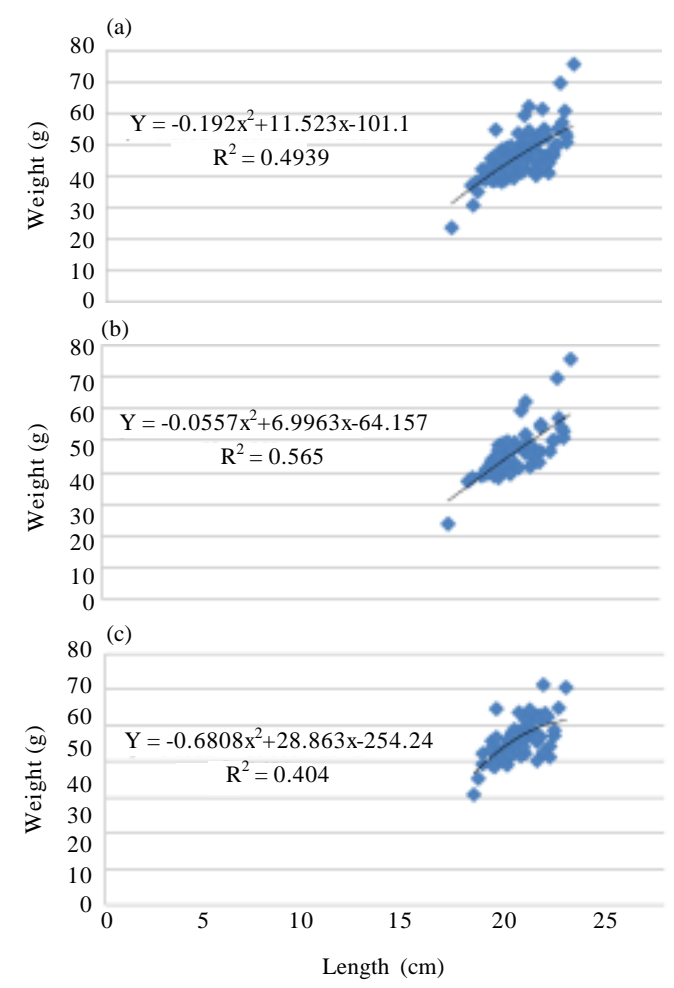

Fig. 2: Length-weight relationships for L. pectoralis: a) All individuals; b) Female and c) Male 
Agric. J., 14 (3): 35-39, 2019

Table 1: Total length-weight relationships of $L$. pectoralis in Menzelet Dam Lake

\begin{tabular}{lccccccc}
\hline Fish/sex & $\mathrm{n}$ & Total length range $(\mathrm{cm})$ & Weight range $(\mathrm{g})$ & LWR $^{*}$ & $\mathrm{~K}$ & Type of growth $(\mathrm{b}=3, \mathrm{p}=0.05)$ \\
\hline $\mathrm{M}$ & 77 & $16.50-20.60$ & $30.81-61.34$ & $\mathrm{~W}=0.039 \mathrm{~L}^{2.418}$ & 0.729 & $\mathrm{~A}(-)$ \\
$\mathrm{F}$ & 73 & $15.50-21.00$ & $23.87-75.65$ & $\mathrm{~W}=1.063 \mathrm{~L}^{1.228}$ & 0.732 & $\mathrm{~A}(-)$ \\
All & 150 & $16.50-21.00$ & $23.87-75.65$ & $\mathrm{~W}=0.067 \mathrm{~L}^{1.778}$ & 0.731 & $\mathrm{~A}(-)$ \\
\hline
\end{tabular}

$\mathrm{K}$ : Condition factor, A (-): Negative allometry growth

are a valuable and standard result of fish sampling programmes. These relationships are considered necessary to estimate various morphological and physiological aspects such as growth rates, length and age structures and other mechanisms of fish population dynamics (Kolher et al., 1995). In fish, the weight is considered to be the function of length (Weatherely and Gill, 1987). LWRs and condition factors of Luciobarbus species has been reported for different populations. Erguden (2016) reported total length as $15.50-33.50 \mathrm{~cm}$ and Weight (W) as 37.00-412.7 g for L. pectoralis collected from Seyhan Reservoir (South-Eastern Anatolia, Turkey). Basiacik et al. (2012) reported that the maximum and minimum values of total length of the $L$. kottelati collected from Adyguzel Dam Lake (Denizli-Turkey) ranged between $13.2-32.3 \mathrm{~cm}$. The range extended from $40.10-572.70 \mathrm{~g}$ for weight. Investigations on the population of the L. esocinus and L. mystaceus inhabiting Keban Dam Lake (Elazig, Turkey) showed that average total lengths were $37.40-49.70$ and $32.20-45.40 \mathrm{~cm}$, respectively. The weight was averaged as $370.40-834.30$ and 304.7-846.70 $\mathrm{g}$ for the same groups of individuals, respectively (Dartay and Gul, 2014).

When the specific gravity of a fish remains unchanged and retains the same shape during its lifetime it is growing isometrically and the value of length exponent b would be exactly 3.0 (Wootton, 1990). Growth in fish stocks is isometric when b value is 3.0. But the growth rate depends on species, sex, age, seasons and feeding (Bagenal and Tesch, 1978) and may be lower or higher than 3 indicating negative and positive allometric growth, respectively. The results of present study revealed that $L$. pectoralis showed negative allometric of growth this type of relationship had been reported in fishes that maintain a constant body shape (Bolaji et al., 2011; Obasohan et al., 2012; Ilhan and Sari, 2015).

The mean condition factors for male and female condition factor of 0.729 and 0.732 , respectively were determined. Coban et al. (2012), reported $\mathrm{K}=0.528-1.865$ for L. esocinus in Keban Reservoir. Average condition factor values reported as between 0.813-1.019 for B. esocinus by Girgin and Sen (1995) between 0.883-1.442 and by Sen et al. (1996) in Keban Dam Lake. Condition factor values change, according to the nutrition condition of the environment, fish age and stress condition and the reproduction activity of the fish (Korkut et al., 2007).

\section{CONCLUSION}

It is well known that the functional regression $b$, value varies according to the body shape of fish and some life history parameters such as maturity, maximum size, growth rate and others factors like habitat, stomach fullness, health, sex, age, etc. The results of this study, provide useful basic biological information about $L$. pectoralis of fish caught in the study area that can also be compared tosurrounding areas like the Menzelet Dam Lake (Kahramanmaras, Turkey).

\section{ACKNOWLEDGEMENT}

This study was presented as a oral presentation at 3rd International Congress on Advances in Veterinary Sciences and Technics (ICAVST), September 4-9, 2018, Belgrade, Serbia.

\section{REFERENCES}

Ayo-Olalusi, C.I., 2014. Length-weight relationship, condition factor and sex ratio of African mud catfish (Clarias gariepinus) reared in flow-through system tanks. J. Fish. Aquat. Sci., 9: 430-434.

Ayyildiz, H., Y. Emre, O. Ozen and A. Yagci, 2014. Age and growth of Capoeta erhani(Actinopterygii: Cypriniformes: Cyprinidae) from the Menzelet reservoir, Turkey. Acta Ichthyologica Et Piscatoria, 44: 105-110.

Bagenal, T.B. and F.W. Tesch, 1978. Age and Growth. In: Methods for Assessment of Fish Production in Fresh Water, Bagenal, T.B. (Ed.). Wiley-Blackwell, Hoboken, New Jersey, USA., ISBN:9780632001255, pp: 101-136.

Bai, V.M.A. and D. Manimegalai, 2010. An analysis of document clustering algorithms. Proceedings of the International Conference on Communication Control and Computing Technologies, October 7-9, 2010, IEEE, Ramanathapuram, India, ISBN:978-1-4244-7769-2, pp: 402-406.

Basusta, N. and E. Cicek, 2006. Length-weight relationships for some teleost fishes caught in Ataturk dam lake on Southeastern Anatolia, Turkey. J. Applied Ichthyol., 22: 279-280. 
Basiacik, S., H.M. Sari, A. Ilhan and M.R. Ustaoglu, 2012. Some growth features of Barbel fish population (Luciobarbus kottelati Turan, Ekmekci, Ilhan and Engin, 2008) in Adiguzel Dam lake (Denizli). J. Fish. Sci. Com., 6: 32-38.

Berg, R.K., 1981. Fish populations of the wild and scenic Missouri River. MSc Thesis, Department of Fish, Wildlife and Park, Montana State Library, Montana, USA.

Bolaji, B.B., T.U. Mfon and D.I. Utibe, 2011. Preliminary study on the aspects of the biology of snakehead fish Parachanna obscura (Gunther) in a Nigerian wetland. Afr. J. Food Agric. Nutr. Dev., 11: 4708-4717.

Coban, M.Z., I. Turkgulu, F. Yuksel, Y. Celayir and S. Yuce et al., 2012. Some biological characteristics of Luciobarbus esocinus Heckel, 1843 living in Keban Reservoir. Turk. J. Fish. Aquat. Sci., 12: 73-80.

Dartay, M. and M.R. Gul, 2014. Length-weight relationships for five fish species caught in Keban Dam Lake, Turkey. J. Appl. Ichthyol., 30: 233-234.

Emre, Y., H. Ayyildiz, O. Ozen and A. Yagci, 2014. Age, growth and otolith morphometry of Capoeta angorae (Cyprinidae) collected from Menzelet Reservoir and Firniz stream (Turkey). Ege. J. Fish. Aquat. Sci., 31: 79-85.

Erguden, S.A., 2016. Length-weight relationships for six freshwater fish species from the Seyhan Reservoir (south-eastern Anatolia, Turkey). J. Appl. Ichthyol., 32: 141-143.

Furuya, V.R., M. Michelato, T.P.D. Cruz and W.M. Furuya, 2014. Length-weight relationships and prediction equations of body composition of farm raised Astyanax aff. Fasciatus (Actinopterygii: Characiformes: Characidae). Zoologia Curitiba, 31: 521-524.

Girgin, A. and D. Sen, 1995. Pullu sazan (Cyprinus carpio Linnaeus, 1758) ile biyikli balik (Barbus esocinus, Heckel, 1843)'in bazi biyolojik ozelliklerinin incelenmesi. Firat Universitesi Fen ve Muhendislik Bilimleri Dergisi, 7: 86-98.

Ilhan, A. and H.M. Sari, 2015. Length-weight relationships of fish species in Marmara Lake, West Anatolia, Turkey. Croatian J. Fish. Ribarstvo, 73: 30-32.

Keyombe, J.L., E. Waithaka and B. Obegi, 2015. Length-weight relationship and condition factor of Clarias gariepinus in Lake Naivasha, Kenya. Intl. J. Fish. Aquat. Stud., 2: 382-385.

Khristenko, D.S. and G.O. Kotovska, 2017. Length-weight relationship and condition factors of freshwater bream Abramis brama (Linnaeus, 1758) from the Kremenchug Reservoir, Middle Dnieper. Turkish
J. Fish. Aquat. Sci., 17: 71-80.

Kirankaya, S.G., F.G. Ekmekci, S. Yalcin-Ozdilek, B. Yogurtcuoglu and L. Gencoglu, 2014. Condition, length-weight and length-length relationships for five fish species from Hirfanli Reservoir, Turkey. J. Fish. Sci. Com., 8: 208-213.

Kolher, N.E., J.G. Casey and P.A. Turner, 1995. Length-weight relationships for 13 species of sharks from the Western North Atlantic. Fish. Bull., 93: 412-418.

Korkut, K.Z., O. Bilgin, I. Baser and N. Saglam, 2007. Stability of grain vitreousness in durum wheat (Triticum durum L. Desf.) genotypes in the North-Western Region of Turkey. Turk. J. Agric. For., 31: 313-318.

Maurya, A.K., K.V. Radhakrishnan, P. Sahu, L. Prasad and S. Khan et al., 2018. Length weight relationship and condition factor of Anabas testudineus (Bloch, 1792) from Rudrasagar Lake (A Ramsar site), Tripura. J. Pharmacog. Phytochem., 7: 1395-1398.

Moutopoulos, D.K. and K.I. Stergiou, 2002. Length-weight and length-length relationships of fish species from the Aegean Sea (Greece). J. Appl. Ichthyol., 18: 200-203.

Obasohan, E.E., J.A. Imasuen and C.E. Isidahome, 2012. Preliminary studies of the length-weight relationships and condition factor of five fish species from Ibiekuma stream, Ekpoma, Edo state, Nigeria. J. Agric. Res. Dev., 2: 61-69.

Ozcan, G., 2008. Length-weight relationships of five freshwater fish species from the Hatay Province, Turkey. J. Fish. Sci. Com., 2: 51-53.

Saha, S.N., P. Vijayanand and S. Rajagopal, 2009. Length-weight relationship and relative condition factor in Thenus orientalis (Lund, 1793) along East coast of India. Curr. Res. J. Biol. Sci., 1: 11-14.

Sen, D., E. Duman, M. Duman and A. Yapar, 1996. [Investigation of bioecological characteristics of Barbus esocinus (Heckel, 1843) and Barbus xanthopterus (Heckel, 1843) populations living in the Keban Dam Lake (InTurkish)]. Firat Univ. J. Sci. Eng. Sci., 8: 113-129.

Serdar, O. and E.I. Ozcan, 2016. Length-weight and length-length relationships of Capoeta umbla in the Karasu River (East Anatolia, Turkey). Aegean J. Fish. Aquat. Sci., 33: 413-416.

Silva, T.S.D.C., L.D.D. Santos, L.C.R.D. Silva, M. Michelato and V.R.B. Furuya et al., 2015. Length-weight relationship and prediction equations of body composition for growing-finishing cage-farmed Nile tilapia. Rev. Bras. de Zootecnia, 44: 
133-137.

Uysal, R., M.A. Yagci, V. Yegen, M. Cesur and A. Yagci et al., 2009. Growth properties of european catfish (Silurus glanis L., 1758) Population in Dznik Lake (Bursa-Turkey). J. Nat. Appl. Sci., 13: 221-228.
Weatherley, A.H. and H.S. Gill, 1987. The Biology of Fish Growth. Academic Press, London, Pages: 443.

Wootton, R.J., 1990. Ecology of Teleost Fishes. 1st Edn., Chapman and Hall, London, UK., ISBN-13: 9780412317200, Pages: 404. 